\title{
Criteria for Measuring the Efficiency and Effectiveness of Human Resources Management Strategy and its Relation to Institutional Performance at Al Rajhi Bank at Al Qassim in Saudi Arabia from the Employees' Point of View
}

\author{
Abdullah M. Alwehabie ${ }^{1}$ \\ ${ }^{1}$ Associate Professor, Qassim University, Saudi Arabia \\ Correspondence: Abdullah M. Alwehabie, Qassim University, Saudi Arabia. E-mail: W.Abdullah@qu.edu.sa
}

Received: June 26, 2017

Accepted: September 5, 2017

Online Published: September 17, 2017

doi:10.5539/ijbm.v12n10p111

URL: https://doi.org/10.5539/ijbm.v12n10p111

\begin{abstract}
The study aimed to identify the efficiency and effectiveness of human resources management strategies in $\mathrm{Al}$ Rajhi bank at Al Qassim, namely human resource planning, selection and recruitment, employee performance evaluation, training of employees and their relation to institutional performance. The study population consisted of (17) branches of Al Rajhi bank at Al Qassim and the study sample consisted of (4) branches of Al Rajhi bank. The study found the following results: There is a positive relationship between the efficiency and effectiveness of human resources planning strategies at Al Rajhi bank and its institutional performance. There is a positive relationship between the efficiency and effectiveness of selection and recruitment strategies at Al Rajhi bank and its institutional performance, as well as a positive relationship between the efficiency and effectiveness of staff training strategies and their institutional performance. Among the recommendations of the study are to analyze the strengths and weaknesses of the internal environment, opportunities and threats to the external environment, and to analyze, describe and classify the functions of the organizational structures of Saudi banks in general and Al Rajhi Bank in particular.
\end{abstract}

Keywords: Human Resource Management Strategy, Human Resources Management, Strategic Management, Strategic Planning, Al Rajhi Bank

\section{Introduction}

Banks play an important role in achieving economic development. They contribute to the provision of financing for sectors to expand its economy and increase its GDP. The last quarter of the twentieth century witnessed many rapid and successive changes in the global economy was the growing trend towards the globalization of economic activity and the emergence of an organization as well as the growing activity of financial markets, information technology and technology.

Human resources are the main wealth of nations, the physical capital and natural resources, despite their importance and necessity. However, without the efficient and well-trained human element, it will be of no value, because human beings are able to use these resources and harness them in production processes to maximize satisfaction. To achieve well-being, the human element with its ability to invent, innovation and development can overcome the scarcity of natural resources and expand the productive potential of society (Zaid, 2008).

The importance of the human element and the need to raise its efficiency have increased the challenges faced by organizations' Globalization, Privatization, Engineering and Competition and the question that can be asked in this context is: How can human resources management perform its tasks, and its goals come in support of the objectives of the organization? The importance of the human element in the productive process has led the organizations to sponsor the activity related to this component by a specialized organizational unit in human resources that works to create an appropriate organizational climate that contributes to the satisfaction of the employees (Abu Sheikha, 2001).

From the foregoing, it is clear that there is no room for the development of any economic sector if not the development of the personnel working in it the sector is the beginning. Examples are many: Japan and Switzerland have relied on human resources that have created a giant economic breakthrough that surpasses all 
imaginations. What is required now is not the leadership that deals with the status quo, but what is required is the leadership that seeks to transform the present into a better future, and manages the change that is inevitably an accident (Kanaan, 1998).

This highlights the importance of managing human resources in general and in Saudi banks in particular in order to choose the most appropriate and appropriate ways to meet the needs of the growth and development stage experienced by the banking sector.

\subsection{Problem of the Study}

The banking system has developed significantly in Saudi Arabia, where the number of banks operating there has increased, and despite this expansion in banking activity; this activity needs continuous follow-up and training of employees permanently. Human resources and human capital development are among the most important tasks of the Saudi banks in terms of providing training and monitoring equipment for the performance of employees. The researcher in this study tries to study the importance of managing human resources in four Saudi banks namely: (Al Rajhi bank, Bank Albilad, and The Saudi Investment Bank, Riyadh bank).

\subsection{Purpose of the Study}

The aim of this study is to identify the efficiency and effectiveness of human resources management strategies at Al Rajhi Bank in Saudi Arabia, namely human resource planning, selection and recruitment, employee performance evaluation, training of employees and their relation to institutional performance.

\subsection{Hypothesis of the Study}

The study seeks to examine the following hypothesis:

1. There is no relationship between the efficiency of HR planning at Al Rajhi Bank in al Qassim/ Saudi Arabia and its institutional performance.

2. There is no correlation between the effectiveness of HR planning at Al Rajhi Bank in al Qassim/ Saudi Arabia and its institutional performance.

3. There is no relationship between the efficiency of selection and recruitment at Al Rajhi Bank in al Qassim/ Saudi Arabia and its institutional performance.

4. There is no relationship between the effectiveness of selection and recruitment at Al Rajhi Bank in al Qassim/ Saudi Arabia and its institutional performance.

5. There is no correlation between the efficiency of evaluation of employees' performance at Al Rajhi Bank in al Qassim/ Saudi Arabia and its institutional performance.

6. There is no correlation between the effectiveness of evaluating employees' performance at Al Rajhi Bank in al Qassim/ Saudi Arabia and its institutional performance.

7. There is no correlation between the efficiency of employee training at Al Rajhi Bank in al Qassim/ Saudi Arabia and its institutional performance.

8. There is no correlation between the effectiveness of employee training at Al Rajhi Bank in al Qassim/ Saudi Arabia and its institutional performance.

\subsection{Definition of Terms}

Efficiency: is an element of the growth and progress of individuals and organizations, and requires an individual's willingness and ability to function so that he can master his work; the two elements of power and desire are the determinants of efficiency. Efficiency is said to be a function of quantity and efficiency as a function of quality.

Effectiveness: Indicates the degree to which the objectives are achieved, as the researcher finds that although efficiency and effectiveness are linked with each other, but efficiency means trying to reach the target with the least cost, time and effort, but effectiveness means reaching the desired goal.

Human Resource Management: Al-Hiti (2000) defines the individuals' management as such management, which functions as planning, organization, recruitment and leadership for the employees in the organization, and human resources management is defined as the department responsible for increasing the effectiveness of human resources in the organization to achieve the objectives of the organization, the individual and society.

Strategic management: is a set of concepts associated with the organizational status to achieve positive results make it effective management of the organization (Jawad, 2000) 
Human Resources Management Strategy: Al-Mursi (2003) believes that the HR strategy including the study, analysis and linkage of human resources activities and the strategies of the Organization, so that the human element becomes one of the weapons to achieve competitive advantage and to improve the organization's market conditions and results of operations

\section{Review of Related Literature}

Some researchers conducted studies about strategic management and human resources, the researcher reviewed some of these studies as follows:

Al - Tahrawi (2010) conducted a study entitled " The role of human resources development strategies in the development of institutional performance in NGOs in the Gaza Strip" The study aimed to identify the role of human resources development strategies in the development of institutional performance through studying the reality of strategic planning for human resource development, the extent to which these strategies are developed professionally, and the level of those who formulate, follow up and evaluate these strategies. Human resources and the ability of these organizations to benefit from these strategies in developing their performance in order to achieve their objectives of continuity, competition and provision of services to the target groups. The researcher applied the same study to (117) non-governmental organizations (13\%) of the original study community by selecting a random class sample of (240) employees (general manager, branch manager, manager, and unit organizer ), the researcher used the questionnaire as a data collection tool. The results revealed that $80 \%$ of NGOs have strategies for human resource development, and that these strategies have contributed to increasing their competitive advantage. The level of development of human resources development strategies in these institutions is also relatively high at (78\%). External participation contributes mainly to the development of these strategies, and $75 \%$ of those who formulate and prepare human resource development strategies have a suitable and appropriate professional level. The results also showed that human resources development strategies have contributed positively to the development of institutional performance in general.

Haddad and Abdel Wahid (2009) conducted a study entitled "The reality of the quality of performance in the institutions of civil work in the Gaza Strip." The aim of the study was to examine the reality of the quality of performance in the civil institutions and to highlight the obstacles and causes of weakness and decline in the quality of performance in the civil institutions in the Gaza Strip (analytical study). The absence of an internal and external regulatory system, as well as the absence of the methodology of codification of previous experiences, the adoption of large centralization, weak motivation in all its material and moral forms, the lack of evaluation of activities, and the absence of databases and information. . The researcher recommended ways of internal treatment for the institution itself and others related to official institutions and competent authorities.

Buckley and Monks (2004) conducted a study aiming at testing perceptions of US HR managers through methods which reflect their competition over the time span of the management process education, and the ways in which they used this competition within cases of their work. The results of the study indicated that the highest scores were for "social and emotional" and "emotional flexibility" There was an increase in participants' perceptions of these two types during the two years.

Dutch (2004) conducted a study which aimed to demonstrate the shortcomings in the field of human resources management by better and better perspective, the results of the study serve multiple levels and help to clarify the perspective of human resources management and the competitive strategy of organizational strategy, organizational culture and industrial norms that improve performance in the human resources system and improve organizational outputs.

Al Khateeb (2003) conducted a study entitled "Strategic planning and institutional performance". This study at The Jordanian pharmaceutical sector - the public shareholding companies - has only been able to identify the reality of strategic planning within this sector through the degree of clarity of the concept, and degree of Practice, sources of information, and the parties involved in this process, and its relationship to institutional performance. One of the most important results reached by the researcher: $52 \%$ of partner managers at The pharmaceutical industry does not realize the correct meaning of the concept of strategic planning, and sees $56 \%$ of the sample of the study is that the strategic planning process is carried out through the higher echelons which reflects a high degree of central decision-making. And that the directors of Jordanian pharmaceutical companies have positive attitudes towards strategic planning and the desired results if applied. There is no relationship between the degree of strategic planning practice and the institutional performance of these companies, whether measured by return on assets or market value added. Strategic and performance, measured by return on assets and market value added, and by firms analyzing the elements of the internal environment and external, and found that managers do not take the elements of the internal and external environment into consideration when undertaking the strategic 
planning process.

Wyper and Harrison (2000) The aim of this study was to apply the six operations approach to human resource management functions for companies with a staff of (1400) employees based on a model developed by Deming, which is a strategy of human resources management, namely the organizational environment, employee development, resource security, reward, communicate, and improve organization. The study concluded that issues related to people in development management are important, such as their fear of change, measurement and dissatisfaction with the status quo, and the need to involve suppliers and customers in the process.

\section{Methodology of the Study}

This study based on the analytical descriptive approach based on field survey and interviews.

\subsection{Population of the Study}

The population of the study consists of all (17) Al Rajhi Bank branches in Al Qassim, four of which were selected as a study sample

\subsection{Unit of Analysis}

The analysis unit represents the human resources departments of Saudi banks selected for this study.

\subsection{The study Sample}

It is a random class sample of workers in (4) branches of Al Rahji Bank at Al Qassim/ Saudi Arabia.

\subsection{The Study tool}

The five-dimensional Likert scale was used for respondents' responses from (1-5) where :(1) strongly disagree, (2) disagree, (3) neutral, (4) agree, (5) strongly agree. The questionnaire was presented to eight arbitrators with expertise in banks. Their contents have been amended on the basis of their opinions and proposals.

\subsubsection{The tool reliability and Validity}

The validity of the questionnaire was tested through the preparation of the questionnaire items and presented it to a panel of (6) arbitrators and management experts, an amended and addition and deletion has been done for each question based on their observations. In addition, Kronbach Alpha test was performed for the questionnaire sections and the questionnaire items obtained a reliability factor of $96.9 \%$. the HR efficiency domain got reliability coefficient (83.1\%) and the domain of efficiency of selection and evaluating employees got $(84.5 \%)$ as the domain of the efficiency of evaluating the performance of employees got the reliability coefficient of (93.5\%), the domain of the efficiency of training the employees got the reliability coefficient of $(88.8 \%)$, as the domain of the effectiveness of HR planning on the coefficient stability got $(60.2 \%)$ and the domain of the effectiveness of the selection and appointment got coefficient reliability of $(87.8 \%)$, as the domain of the effectiveness of evaluating employees' performance got the reliability coefficient of $(81.3 \%)$, and the domain of the effectiveness of training the employees got a reliability coefficient of (75.5\%),Since Alpha is greater than the acceptable rate of $60 \%$, this indicates the reliability of the measuring instrument.

\section{Results of the Study}

The following decision base has been relying on in the test Hypotheses:

The null hypothesis $(\mathrm{Ho})$ is accepted if the moral value is greater than the significance level $5 \%$.

The null hypothesis (Ho) is rejected if the moral value is less than the significance level $5 \%$.

The first hypothesis

Ho: There is no relationship between the efficiency of HR planning at Al Rajhi Bank in al Qassim/ Saudi Arabia and its institutional performance.

Ha: There is a relationship between the efficiency of HR planning at Al Rajhi Bank in al Qassim/ Saudi Arabia and its institutional performance.

(Pearson) correlation coefficient test was used to test the hypothesis above, where the results are summarized in Table 1. 
Table 1. The efficiency of human resources planning at Al Rajhi Bank in al Qassim/ Saudi Arabia and its relation to institutional performance

\begin{tabular}{llll}
\hline Dimensions of performance & Sig & Correlation coefficient & Result \\
\hline market share & 0.00 & 0.401 & There is a relationship \\
Profitability & 0.00 & 0.539 & There is a relationship \\
Public satisfaction & 0.00 & 0.554 & There is a relationship \\
The degree of leadership support & 0.00 & 0.395 & There is a relationship \\
Degree of gains and results & 0.00 & 0.406 & There is a relationship \\
\hline
\end{tabular}

The results in Table 1 show that there is a statistically significant positive relationship at the significance level (0.00) between planning efficiency of Human resources and every dimension of institutional performance, as it turns out that the strongest relationship was with the public satisfaction dimension, where the value of Pearson correlation coefficient was (0.554), the weakest relationship was with the degree of leading support dimension, because the correlation coefficient was $(0.395)$.

The second hypothesis

Ho: There is no correlation between the effectiveness of HR planning at Al Rajhi Bank in al Qassim/ Saudi Arabia and its institutional performance.

Ha: There is a correlation between the effectiveness of HR planning at Al Rajhi Bank in al Qassim/ Saudi Arabia and its institutional performance.

Pearson correlation coefficient test was used to test the above hypothesis, where the results are summarized in Table 2.

Table 2. The efficiency of human resources planning at Al Rajhi Bank in al Qassim/ Saudi Arabia and its relation to institutional performance

\begin{tabular}{llll}
\hline Dimensions of performance & Sig & Correlation coefficient & Result \\
\hline market share & 0.00 & 0.389 & There is a relationship \\
Profitability & 0.00 & 0.412 & There is a relationship \\
Public satisfaction & 0.00 & 0.778 & There is a relationship \\
The degree of leadership support & 0.00 & 0.795 & There is a relationship \\
Degree of gains and results & 0.00 & 0.493 & There is a relationship \\
\hline
\end{tabular}

The results in table 2 show that there is a statistically significant positive relationship at the significance level (0.00) between planning efficiency and Human resources and every dimension of institutional performance, as it shows also the strongest relationship was with the degree of leadership support dimension, where Pearson correlation coefficient reached $(0.795)$, the weakest relation was for the market share dimension, because the correlation coefficient reached (0.389).

The third hypothesis

Ho: There is no relationship between the efficiency of selection and recruitment at Al Rajhi Bank in al Qassim/ Saudi Arabia and its institutional performance.

Ha: There is a relationship between the efficiency of selection and recruitment at Al Rajhi Bank in al Qassim/ Saudi Arabia and its institutional performance.

Pearson correlation coefficient test was used to test the above hypothesis, where the results are summarized in Table 3. 
Table 3. Effectiveness of human resources planning at Al Rajhi Bank in al Qassim/ Saudi Arabia and its relation to institutional performance

\begin{tabular}{llll}
\hline Dimensions of performance & Sig & Correlation coefficient & Result \\
\hline market share & 0.00 & 0.401 & There is a relationship \\
Profitability & 0.00 & 0.527 & There is a relationship \\
Public satisfaction & 0.00 & 0.581 & There is a relationship \\
The degree of leadership support & 0.00 & 0.424 & There is a relationship \\
Degree of gains and results & 0.00 & 0.554 & There is a relationship \\
\hline
\end{tabular}

The results in table 3 shows that there is a statistically significant positive relationship at the significance level $(0.00)$ between efficiency of selection strategies, recruitment and each dimension of Institution's performance, as it shows that the strongest relationship was with the satisfaction of the public dimension, were Pearson correlation coefficient reached $(0.581)$ the weakest relationship, however, was with the market share because the correlation coefficient was $(0.401)$.

The fourth hypothesis

Ho: There is no relationship between the effectiveness of selection and recruitment at Al Rajhi Bank in al Qassim/ Saudi Arabia and its institutional performance.

Ha: There is a relationship between the effectiveness of selection and recruitment at Al Rajhi Bank in al Qassim/ Saudi Arabia and its institutional performance.

Pearson correlation coefficient test to test the above hypothesis, where the results are summarized in Table (4)

Table 4. The effectiveness of selection and recruitment at Al Rajhi Bank in al Qassim/ Saudi Arabia and its relation to institutional performance

\begin{tabular}{llll}
\hline Dimensions of performance & Sig & Correlation coefficient & Result \\
\hline market share & 0.00 & 0.308 & There is a relationship \\
Profitability & 0.00 & 0.352 & There is a relationship \\
Public satisfaction & 0.00 & 0.461 & There is a relationship \\
The degree of leadership support & 0.00 & 0.760 & There is a relationship \\
Degree of gains and results & 0.00 & 0.948 & There is a relationship \\
\hline
\end{tabular}

The results in table 4 shows that there is a statistically significant positive relationship at the significance level $(0.00)$ between the effectiveness of the selection and recruitment and every dimension of institutional performance, as it shows that the strongest relationship was with the degree of gains and results dimension, where Pearson correlation coefficient reached (0.948) while the weakest relationship was the market share dimension were the correlation coefficient reached $(0.308)$.

The fifth hypothesis

Ho: There is no correlation between the efficiency of employees' performance appraisal at Al Rajhi Bank in al Qassim/ Saudi Arabia and its institutional performance.

Ha: There is a correlation between the efficiency of employees' performance appraisal at Al Rajhi Bank in al Qassim/ Saudi Arabia and its institutional performance.

Pearson correlation coefficient test was used to test the above hypothesis, where the results are summarized in Table 5.

Table 5. The efficiency of evaluating the performance of employees at Al Rajhi Bank in al Qassim/ Saudi Arabia and its relation to institutional performance

\begin{tabular}{llll}
\hline Dimensions of performance & Sig & Correlation coefficient & Result \\
\hline market share & 0.00 & 0.545 & There is a relationship \\
Profitability & 0.00 & 0.616 & There is a relationship \\
Public satisfaction & 0.00 & 0.681 & There is a relationship \\
The degree of leadership support & 0.00 & 0.460 & There is a relationship \\
Degree of gains and results & 0.00 & 0.577 & There is a relationship \\
\hline
\end{tabular}


The results in table 5 shows that there is a statistically significant positive relationship at the significance level $(0.00)$ between the efficiency of evaluating the employees' performance and each dimension of institutional performance, it shows also that the strongest relationship was with the public satisfaction dimension, where the value of Pearson correlation coefficient reached $(0.681)$, and the weakest relationship was with the degree of leading support dimension because the correlation coefficient reached. (0.460).

The sixth hypothesis

Ho: There is no correlation between the effectiveness of evaluating employees' performance at Al Rajhi Bank in al Qassim/ Saudi Arabia and its institutional performance.

Ha: There is a correlation between the effectiveness of evaluating employees' performance at Al Rajhi Bank in al Qassim/ Saudi Arabia and its institutional performance.

Pearson correlation coefficient test was used to test the above hypothesis, where the results are summarized in Table 6.

Table 6. Effectiveness of assessing the performance of employees at Al Rajhi Bank in al Qassim/ Saudi Arabia and its relation to institutional performance

\begin{tabular}{llll}
\hline Dimensions of performance & Sig & Correlation coefficient & Result \\
\hline market share & 0.00 & 0.498 & There is a relationship \\
Profitability & 0.00 & 0.603 & There is a relationship \\
Public satisfaction & 0.00 & 0.590 & There is a relationship \\
The degree of leadership support & 0.00 & 0.430 & There is a relationship \\
Degree of gains and results & 0.00 & 0.623 & There is a relationship \\
\hline
\end{tabular}

The results in Table 6 show that there is a positive statistical significant relationship at the significance level (0.00) between the effectiveness of the evaluation of the employee's performance and each dimension of institutional performance, it shows that the strongest relationship was with the degree of gains and results, where Pearson correlation coefficient reached (0.623) while the weakest relationship was with the degree of leading support because the correlation coefficient reached $(0.43)$

The seventh hypothesis

Ho: There is no correlation between the efficiency of staff training at Al Rajhi Bank in al Qassim/ Saudi Arabia and its institutional performance.

Ha: There is a correlation between the efficiency of staff training at Al Rajhi Bank in al Qassim/ Saudi Arabia and its institutional performance.

Pearson correlation coefficient test was used to test the above hypothesis, where the results are summarized in Table 7.

Table 7. The efficiency of training of employees at Al Rajhi Bank in al Qassim/ Saudi Arabia and its relation to institutional performance

\begin{tabular}{llll}
\hline Dimensions of performance & Sig & Correlation coefficient & Result \\
\hline market share & 0.00 & 0.885 & There is a relationship \\
Profitability & 0.00 & 0.908 & There is a relationship \\
Public satisfaction & 0.00 & 0.747 & There is a relationship \\
The degree of leadership support & 0.00 & 0.344 & There is a relationship \\
Degree of gains and results & 0.00 & 0.378 & There is a relationship \\
\hline
\end{tabular}

The results in table 7 shows that there is a statistically significant positive relationship at the significance level $(0.00)$ between efficiency of training employees and every dimension of the institutional performance, as it also showed that the strongest relationship was with the profit dimension, where the value of Pearson correlation coefficient reached $(0.908)$, the weakest relation was with a degree of leading support dimension because the correlation coefficient reached (0.344).

The eighth hypothesis 
Ho: There is no correlation between the effectiveness of employee training at Al Rajhi Bank in al Qassim/ Saudi Arabia and its institutional performance.

Ha: There is no correlation between the effectiveness of employee training at Al Rajhi Bank in al Qassim/ Saudi Arabia and its institutional performance.

Pearson correlation coefficient test was used to test the above hypothesis, where the results are summarized in Table 8 .

Table 8. Effectiveness of training of employees at Al Rajhi Bank in al Qassim/ Saudi Arabia and its relation to institutional performance

\begin{tabular}{llll}
\hline Dimensions of performance & Sig & Correlation coefficient & Result \\
\hline market share & 0.00 & 0.602 & There is a relationship \\
Profitability & 0.00 & 0.680 & There is a relationship \\
Public satisfaction & 0.00 & 0.628 & There is a relationship \\
The degree of leadership support & 0.00 & 0.320 & There is a relationship \\
Degree of gains and results & 0.00 & 0.366 & There is a relationship \\
\hline
\end{tabular}

The results in table 8 shows that there is a statistically significant positive relationship at the significance level $(0.00)$ between the efficacy of employee training strategies and each dimension of Institution's performance, as it also showed that the strongest relationship was with the profitability dimension, Pearson correlation coefficient was $(0.680)$ while the weakest relationship was with the degree of gains and results dimension because the correlation coefficient was $(0.320)$.

\subsection{Discussion of the Results}

Ho.1: There is no relationship between the efficiency of HR planning at Al Rajhi Bank in al Qassim/ Saudi Arabia and its institutional performance.

To test this hypothesis Pearson correlation analysis was used, and in our reading of the results of the computer in table 1 we find that the moral value is less than the significance level of $5 \%$, which means rejection of the nihilistic hypothesis and acceptance of the alternative hypothesis. That means there is a statistically significant relationship between the efficiency of HR planning at Al Rajhi Bank in al Qassim/ Saudi Arabia and between every dimension of the dimensions of institutional performance, also show that the strongest relationship was with the public satisfaction dimension were Pearson correlation coefficient reached $(0.554)$.

Ho.2: There is no correlation between the effectiveness of HR planning at Al Rajhi Bank in al Qassim/ Saudi Arabia and its institutional performance.

To test this hypothesis Pearson correlation analysis was used, and in our reading of the results of the computer in table 2 we find that the moral value is less than the significance level of $5 \%$, which means rejection of the nihilistic hypothesis and acceptance of the alternative hypothesis. That means there is a statistically significant relationship between the effectiveness of HR planning at Al Rajhi Bank in al Qassim/ Saudi Arabia and between each dimension of institutional performance. It was also found that the strongest relationship was with the degree of leadership support. The Pearson correlation coefficient reached (0.795).

Ho.3: There is no relationship between the efficiency of selection and recruitment at Al Rajhi Bank in al Qassim/ Saudi Arabia and its institutional performance.

To test this hypothesis Pearson correlation analysis was used, and in our reading of the results of the computer in table 3 we find that the moral value is less than the level of significance of $5 \%$, which means rejecting the nihilistic hypothesis and accepting the alternative hypothesis. This means that there is a statistically significant relationship between the efficiency of selection and recruitment at Al Rajhi Bank in al Qassim/ Saudi Arabia and between each of the following dimensions of institutional performance, also it shows that the strongest relationship was with the public satisfaction dimension, Pearson correlation coefficient was reached. (0.581).

Ho.4: There is no correlation between the effectiveness of selection and recruitment at Al Rajhi Bank in al Qassim/ Saudi Arabia and its institutional performance.

To test this hypothesis Pearson correlation analysis was used, and in our reading of the results of the computer in table 4 we find that the moral value is less than the significance level of $5 \%$, which means rejection of the nihilistic hypothesis and acceptance of the alternative hypothesis. That means there is a statistically significant 
relationship between the effectiveness of selection and recruitment at Al Rajhi Bank in al Qassim/ Saudi Arabia and between each dimension of Institutions' performance, it also showed that the strongest relationship was with the degree of gains and results dimension, were Pearson correlation coefficient reached (0.948).

Ho.5: There is a correlation between the efficiency of employees' performance appraisal at Al Rajhi Bank in al Qassim/ Saudi Arabia and its institutional performance.

To test this hypothesis Pearson correlation analysis was used and through our reading of the results of the computer in table 5 we find that the moral value is less than the level of significance of $5 \%$, which means rejecting the nihilistic hypothesis and accepting the alternative hypothesis. and this means that there is a statistically significant relationship between assessment efficiency of employee' performance at Al Rajhi Bank in al Qassim/ Saudi Arabia and between each dimension of the dimensions of institutional performance, as it showed that the strongest relationship was with public satisfaction dimension, were Pearson correlation coefficient reached $(0.681)$.

Ho.6: There is no correlation between the effectiveness of evaluating employees' performance at Al Rajhi Bank in al Qassim/ Saudi Arabia and its institutional performance.

To test this hypothesis Pearson correlation analysis was used, and in our reading of the results of the computer in table 6 we find that the moral value is less than the level of significance of $5 \%$, which means rejecting the nihilistic hypothesis and accepting the alternative hypothesis. This means that there is a statistically significant relationship between the efficacy of an assessment of the performance of employees at Al Rajhi Bank in al Qassim/ Saudi Arabia and between each dimension of institutional performance, and it was found that the strongest relationship was with the degree of gains and results dimension, where the value of Pearson correlation coefficient reached (0.623).

Ho.7: There is no correlation between the efficiency of staff training at Al Rajhi Bank in al Qassim/ Saudi Arabia and its institutional performance.

To test this hypothesis Pearson correlation analysis was used, and through our reading of the results of the computer in table 10 , we find that the moral value is less than the level of significance $(5 \%)$ which means rejecting the nihilistic hypothesis and accepting the alternative hypothesis. This means that there is a statistically significant relationship between efficiency of training employees at Al Rajhi Bank in al Qassim domain and among all the dimensions of institutional performance, it also shows that the strongest relationship was with the profitability dimension, where the value of Pearson correlation coefficient reached (0.908).

Ho.8: There is no correlation between the effectiveness of employee's training at Al Rajhi Bank in al Qassim/ Saudi Arabia and its institutional performance.

To test this hypothesis Pearson correlation analysis was used, and in our reading of the results of the computer in table 8 we find that the moral value is less than the level of significance of $5 \%$, which means rejecting the nihilistic hypothesis and accepting the alternative hypothesis. This means that there is a statistically significant relationship between the effectiveness of training the employees at Al Rajhi Bank in al Qassim/ Saudi Arabia and between each dimension of institutional performance, and it was found that the strongest relationship was with the profitability dimension, where the value of Pearson correlation coefficient reached $(0.680)$.

\section{Recommendations}

Based on the study findings, the following recommendations were made

1. Saudi banks should continue to plan their human resources by identifying the number of employees they need in the future, taking disciplinary action for those who are late or absent from work, promoting employees on a fair basis, identifying the skills, expertise and capabilities they need in the future, and the development of English language skills among workers. This is done through the proper analysis, classification and classification of jobs by the banks, which helps them to increase the efficiency of their human resources planning.

2. Saudi banks should continue to link their human resources planning with the ultimate objectives of the bank. This will be through the formulation of vision, mission, objectives and strategies for human resources planning based on the strategies adopted by the bank.

3. Saudi banks should continue to select and recruit employees based on the application for recruitment and knowledge of their abilities to deal with others, their ability to lead, knowledge of their intelligence levels, their motivation to work, and their personal testing and interviews, and this comes through the belief the Saudi banks have to put the right man in the right place. 
4. The Saudi banks should take into consideration in the selection process and recruitment of the employees to put an advertisement in the various media, and avoid the recruitment by means of mediation, and to take care of the medical examination process prior the recruitment, as well as attention to the skills of English language and computer. This is through Banks' faith to put the right man in the right place.

5. The Saudi banks should continue to design training programs that serve their objectives and train employees to ensure the achievement of these objectives, and this is through the banks' belief in the importance of training and its positive reflection on the effectiveness of working in it.

6. Saudi banks should continue to train employees in training courses to increase their knowledge, skills and abilities, modify their behavior, and increase their ability to communicate with others. This is by informing employees about the importance of training courses for them and for the Bank and motivating them to participate in these courses.

\section{References}

Abu Sheikha, N. (2001). Human Resources Management (1st ed). Dar Safa for Publishing and distribution.

Al-Hiti, Kh. (2000). Human Resources Management, Strategic Introduction. Al Hamed Library House.

Al-Mursi, J. (2003). Strategic Management of Human Resources: Introduction to the competitive advantage of the 21st Century Organization. Alexandria, University House.

Buckley, F., \& Monks, K. (2004). The Implications of Meta - Qualities for HR Role. Human Resource Management Journal, 14(4).

Dutch, M. (2004) Applying an Expanded Contingency Perspective to Assess the Appropriateness of SHRM $\begin{array}{lllll}\text { Practices (PhD, Hniversity } & \text { Houston). } & \text { Retrieved }\end{array}$ http://wwwlib.umi.com/dissertations/preview-all/3131266

Haddad, I., \& Abdel Wahed, M. (2009). The reality of quality of performance in the labor institutions in the Gaza Strip "An Analytical Study, A Study Presented to the Conference on the Reality of Institutions Eligibility and Challenges "Gaza-Palestine.

Jawad, Sh. (2000). Strategic Management (1st ed.). Dar Al-Hamed Publishing and Distribution.

Kanaan, T. (1998). Human Resource Development and Economic Growth in the Arab Countries. UAE: Arab Monetary Fund, Arab Fund for Economic and Social Development, 1998

Khatib, S. (2003). Strategic Planning and Institutional Performance an Analytical Study for the Jordanian pharmaceutical industry. Unpublished Ma thesis, University of Jordan, Amman.

Tahrawy, A. (2010). The role of human resources development strategies in the development of institutional performance in non-governmental organizations in GazaPublished. Islamic University-Gaza-Palestine

Wyper, B., \& Harrison, A. (2000). Deployment of Six Sigma Methodology in Human Resourse Function: A Case Study (Total Quality Management).

Zaid, B. (2008). The reality of the management and development of human resources in banks operating in Palestine. Un-published Master thesis, Gaza Islamic University.

\section{Copyrights}

Copyright for this article is retained by the author(s), with first publication rights granted to the journal.

This is an open-access article distributed under the terms and conditions of the Creative Commons Attribution license (http://creativecommons.org/licenses/by/4.0/). 